\title{
Investigation on the life status of the land-lost farmers in Xinjiang and research on countermeasures
}

\author{
Liu Yinxia, Zhang Aiping \\ College of Economic and Management, Tarim University, Alar, Xinjiang 843300
}

Keywords: Land-lost farmers, Xinjiang, Countermeasures

\begin{abstract}
Xinjiang, especially with the acceleration of new industrialization and new-type urbanization process, the demands on land has sharply increased while the scale of land expropriation and relocation has been larger and larger, meanwhile, the number of land-lost farmers has increased, moreover, the government has faced many problems in the process of arranging these land-lost farmers owing to various factors, which should be highly valued by us.
\end{abstract}

\section{Introduction}

The land-lost farmers refer to the farmers who go to the urban areas owing to the land expropriation caused from urban expansion in the urbanization development process. In recent years, with the rapid development of the social economy in Xinjiang, the lands of more and more farmers have been expropriated, which causes more and more farmers to lose their lands, however, the author finds there exists with many problems based on the due investigation on the settlement and employment of the land-lost farmers.

\section{The problems existed in the settlement of the land-lost farmers in Xinjiang}

Currently, monetary compensation is prevailing in the different regions of Xinjiang in the compensation process for land expropriation. Because this compensation mode is simple, direct and easily accepted by the land-lost farmers. The government can obtain lands quickly and conduct development by aid of the mode. But this compensation mode is featured with short-term characteristic. The land-lost farmers can obviously improve their living conditions within short time after they get the money, which seems to be much, and they can use the money to build houses or buy houses in the cities, besides, they can conduct investment for entrepreneurship and even make consumption. However, many farmers can not make good use of the money owing to their cultural quality and values, which makes them spend the money quickly within certain period.

In the process of land expropriation and demolishing in Xinjiang, the land compensation standard is basically calculated in accordance with the multiple of the agricultural outputs of the lands expropriated. From the perspective of the production and management benefits of the rural lands, the annual earnings for the land of one mu are generally hundreds to thousands of RMB, therefore, the compensation amount is limited to remedy the losses in production and life for the land-lost farmers. In addition, the economic development levels in different regions are different and the fiscal strengths of the governments are uneven, therefore, the execution standards are inconsistent in the actual compensation. Some local governments reduce the compensation standard on purpose in order to attract the investors in the investment attraction process. Besides, the governments lack of dynamic adjustment in the compensation standard, don't adjust the compensation standard timely in accordance with the changing of the social production and the life, but instead, continue to make compensation according to the original standard,which causes the compensation amount can not meet with the long-term production and life of the land-lost farmers, and makes the farmers trapped in a difficult situation. 
The social security system is weak in the rural areas of our country with narrow coverage and lower level, for the farmers, the land undertakes the dual functions of production material and social security. Once the farmers lose the lands owing to land expropriation, they will have no methods to enjoy or instantly enjoy the social security treatment of urban level and their survival rights will not be guaranteed, which will cause troubles for long-term survival. Currently, the social security coverage for the land-lost farmers is narrow and the security level is low, meanwhile, few farmers seeking jobs on their own participate in the social insurance, while the insurance participation rate of medical care and endowment is lower, but from the perspective of the elderly and disabled, the endowment insurance needs to be urgently solved.

With the urbanization development, the governments have had a sharp increase in lands and the land finance has occupied a larger proportion in the revenue of various-level governments, which prompts the various-level governments to constantly expropriate and utilize the lands thus to increase the local financial revenue relying on land appreciation. Therefore, the land incomes are largely different before and after the land expropriation. The land expropriation of one mu from the farmers costs only tens of thousands of Yuan to one hundred thousand Yuan for compensation while the governments can sell the land to the developers with the price of hundreds of thousands of Yuan and even higher price after reformation, which causes the serious unbalance in the mentalities of the farmers thus to generate discontent and make the farmers have antipathy for the land expropriation by the governments, and further, the antipathy will be likely to be evolved to confrontation to cause the mass disturbance thus to have adverse influence on the social stability.

Land is the important basis for farmers to make a living, losing the land means the losing of the basic guarantee for farmers in later life, which causes them to face acid test in birth, senility, illness and death,if they can not obtain the alternative guarantee, they will completely become the poor people thus to cause serious social problem. Currently, from the perspective of the land compensation mode, the local governments also adopt some job arrangement methods, issue and formulate some policies supporting employment and bring partial capitals out of the land incomes for the employment training on the land-lost farmers thus to help the land-lost farmers to master the employment skills, in addition, the governments provide the public-benefit or other employment positions to solve the employment problem for the land-lost farmers and guarantee them to have stable incomes. However, most land-lost farmers will face the problem of difficulty in employment owing to the influence from their own cultural knowledge, employment skills, life modes, language communication and employment ideas.

\section{Analysis on the reasons for the settlement problems of land-lost farmers in Xinjiang}

From the perspective of land expropriation in rural areas, the various-level government departments mainly rely on the Land Management Method and the stipulations or policies formulated by themselves. The governments stand on their own side in formulating the stipulations and policies, therefore, the stipulations and polities tend to be advantageous for the governments while the farmers are still in the weak position, which is the most important source of the settlement problems for farmers.

The local governments in Xinjiang pay high attention to the social security problem for the landlost farmers, issue and formulate some policies and measures on the social security for the land-lost farmers. For example, Yining City formulates the Implementation Methods (provisional) on Social Security for the Land-lost Farmers and Herdsmen thus to practically guarantee the endowment and medical guarantee for the land-lost farmers and herdsmen. Currently, there are nearly 30000 landlost farmers and herdsmen in Yining. In accordance with the implementation method, they are gradually being incorporated in the social security management. Besides, Korla city formulates the Social Security Interim Procedures for the Land-lost Farmers in Korla City thus to gradually solve the social security problem for the nearly 20000 land-lost farmers. But there still exists with the problems in the real life, such as the low social security level, the difference from the real life level, and low insurance participation enthusiasm of land-lost farmers, which cause partial land-lost farmers to be in the situation of no reliance and endowment. 
Though the local governments formulate and issue many settlement methods and measures in the settlement process for the land-lost farmers as well as solve some settlement problems for the landlost farmers, on the whole, some local government departments implement the various settlement policies poorly thus to cause the losses of the legal rights and interests of some land-lost farmers, and cause their dissatisfaction. From the perspective of solving the reemployment for the land-lost farmers, some enterprises fail to perform their promises after completing the land expropriation,in addition, some enterprises have so high technology contents to need higher labor quality, while the land-lost farmers are generally low in their qualities, therefore, the employment is very difficult.

In the current land expropriation and settlement process of the governments, it mainly aims at the farmers, especially the minority farmers, who have low education degree, poor language communication capability, conservative and backward thoughts and ideas as well as insufficient labor skills, and even some people only engage in agricultural production in their whole life without other experiences, therefore, once their lands are appropriated, they will instantly be trapped in the unemployment situation. But on the whole, the reemployment situation for the land-lost farmers is not optimistic, many farmers are conservative in employment ideas and have no understanding on the employment policies of the governments. In the employment training made by the government, the land-lost farmers have low participation enthusiasm in the employment training and even some farmers are not willing to participate, which cause the settlement difficulty.

\section{Suggestions on the settlement policies for the land-lost farmers}

Start from establishing the social relief and security system for land-lost farmers and promoting the endowment insurance for land-lost farmers, establish the basic life security system framework for the land-lost farmers. Based on full investigation and research as well as repeated demonstration, further perfect the compensation and settlement methods and the basic life security and settlement methods for land-lost farmers and practically solve the worries of the farmers.

The current settlement mode for the land-lost farmers in Xinjiang is single, most farmers can only accept the settlement and compensation passively owing to the few choices. While the diversified settlement requirements, in accordance with the economic, cultural and social situations of the local area, give full play to the roles of the governments, enterprises and land-lost farmers, combine the employment and settlement compensation, endowment insurance and medical insurance, thus to fully guarantee the interests of the land-lost farmers. In addition, it is needed to change the one-off monetary compensation method, strengthen the supervision and management on the settlement and compensation fund thus to guarantee the land-lost farmers to obtain the compensation money, establish the specialized fund operation and management institutions to be responsible for the fund raising, investment operation and fund releasing.

Reemployment is the fundamental channel to solve the survival and development of the land-lost farmers. It needs to pay attention to the following aspects in establishing the employment security system for the land-lost farmers: firstly, perfect the employment service system for the land-lost farmers, build the employment training fund for them, classify their employment skills, enhance their quality and skills, and release the skill certificate to them; secondly, positively provide the entrepreneurial chances for them, starting from their own features, positively help them to give full play to their advantages, encourage them to start up their own businesses, provide the preferential policies on field, taxation and loan for them; finally, establish the effective and smooth employment information service network, largely develop the intermediary organization for them and provide good platform for employment and entrepreneurship.

Combined with the specific situation of the land-lost farmers, under the premise of coordinating the relationship with the rural cooperative medical service, handle the medical security work for the land-lost farmers well. Persist in the principle of adjusting measures to local conditions, establish the multi-mode and multi-level medical security system, and establish the common-investment of the country, group and individuals and risk-sharing mechanism. Focus on the following aspects: firstly, establish the social medical assistance system for the land-lost farmers; secondly, the commercial insurance is an important channel or supplement mode, 
therefore, the critical illness insurance for land-lost farmers can be insured; finally, establish the new cooperative medical insurance system in the regions with proper situations.

\section{References}

[1] Wen Lizheng . Survey on the settlement for the land-lost farmers in Shihezi of Xinjiang and countermeasure [J]. Agricultural science periodical, 2015(05) : 24-24.

[2] Zhang Yiing, Wang Lin and Pan Liping. Thinking on the petitioning of the land-lost farmers in Xinjiang [J]. Economic Research Guide, 2015(19) : 326-327.

[3] Huang Lijie, Zhang Min. Main problems existed in the social security for the land-lost farmers in Hutubi County of Xinjiang and countermeasures[J]. Agriculture and technology, 2014 (01) : 208-209.

[4]Ma Qin and Maimai Tijiang . Survey and research on the life status of the land-lost farmers in the new region construction in Wusu of Xinjiang[J]. Agricultural science periodical, 2013(09) : 2930 .

[5]Li Xiaoxia . Employment and social security problem for the land-lost farmers in the rapid urbanization process in Xinjiang[J]. Seek truth from facts, 2014, (5). 